\title{
DOMESTIC AND FOREIGN FINANCING SOURCES IMPACT ON THE ECONOMIC DEVELOPMENT OF THE REPUBLIC OF SERBIA
}

\author{
UDC 330.34:336(497.11)
}

\author{
Goran Radisavljević ${ }^{1}$, Goran Milovanović ${ }^{2}$, Saša Bjeletić ${ }^{3}$ \\ ${ }^{1}$ Municipality of Sokobanja, Republic of Serbia \\ ${ }^{2}$ University of Niš, Faculty of Economics Niš, Republic of Serbia \\ ${ }^{3}$ Unaffiliated researcher, Bor, Republic of Serbia
}

\begin{abstract}
The aim of the paper is to analyze the effects of selected sources of financing on the economic development of the Republic of Serbia in the period from 2012 to 2016 on the basis of systematized statistical data. First, the theoretical framework of domestic and foreign sources of financing and the impacts of these sources on economic development are presented from the perspective of contemporary theory. This is followed by the analysis of the impact of domestic sources of financing (domestic savings, state and private sector) on the economic development of the Republic of Serbia. Finally, the paper examines the relevance of foreign direct investment (FDI) for encouraging restructuring, competitiveness, growth, and development of the economy of the Republic of Serbia.
\end{abstract}

Keywords: domestic sources, foreign sources, FDI, GDP, economic development

JEL Classification: F21, P45, R42

\section{INTRODUCTION}

Economic development includes a series of quantitatively rather different, socioeconomic changes characteristic of the continuous transformation of the economy and society. In a nutshell, economic development includes changes in the volume of production and complex transformations in the composition and structure of the economy (Cvetanović, 2005 , p. 8). In addition to the growth in the volume of national production, economic development includes complex structural, institutional, organizational and technological

Received January 01, 2019 / Revised April 23, 2019 / Accepted May 03, 2019

Corresponding author: Goran Milovanović

University of Niš, Faculty of Economics, Trg kralja Aleksandra 11, 18000 Niš, Serbia

E-mail: goran.milovanovic@eknfak.ni.ac.rs 
changes in the economy, which enable the increased production to be achieved on the national or foreign markets.

Financing economic development is a central issue in the financial system of all countries. The development of the financial system and the establishment of appropriate financial mechanisms are necessary for the effective engagement of domestic and foreign sources of financing and their allocation to profitable projects driving the economic development. The analysis of the sources of economic development financing in the Republic of Serbia should be considered in the context of the financial position of certain institutional economic sectors. The main institutional sectors in each national economy, including that of the Republic of Serbia, are 1) the household sector, 2) the government sector, 3) the business sector and 4) the foreign sector.

\section{THE IMPACT OF DOMESTIC AND FOREIGN SOURCES OF FINANCING ON ECONOMIC DEVELOPMENT - THEORETICAL FRAMEWORKS}

Domestic savings, as a key source of economic development financing, are voluntary refraining from spending in the present to increase consumption in the future. Walt Rostow points out that the key condition for certain national economies to overcome the state of underdevelopment is the savings rate between 10 and 15 percent (Rostow, 1963). Due to the significant role of profit in shaping the business sector savings and thus the overall national savings, some economists emphasize that profit plays a key role in financing economic development. Because of this role, profits are often subject to justifiable disputes (Lewis, 1966, pp. 120-121). As a rule, industrialized countries base their development on investments resulting from domestic savings. On the contrary, in most developing countries, the biggest problem of financing economic development is insufficient domestic savings. The result are too low investments in production capital that are necessary for the rapid economic development of developing countries (Samuelson \& Nordhaus, 1992, p. 698).

Today all countries have open economies, to a greater or lesser extent. Therefore, when considering the financing of economic development, it is necessary to analyze not only domestic but also foreign sources of financing. Foreign capital, as an additional source of financing, is imposed in underdeveloped economies as a condition of changing their structure and adapting to the world market requirements (Todorović, 1998, pp. 15-16). Arnold and Javorick have proven that foreign ownership leads to a significant improvement in the productivity of purchased companies (Arnold \& Javorcik, 2009, pp. 42-53).

Based on an analysis of the functioning of the Central and Eastern Europe economies, which have had a significant inflow of FDI from the early 1990s, Hagemeyer and Tyrowicz concluded that foreign companies in these countries showed superior performances compared to domestic companies (Hagemeyer \& Tyrowicz, 2012, pp. 195-233). Moura and Forte point out that governments play a key role in creating conditions for the positive effects of FDIs or reducing their negative effects on the economic growth and development of recipient countries (Moura \& Forte, 2010). In the case of a lack of domestic sources of financing, FDIs are the most desirable source of financing economic development. 


\section{DOMESTIC SOURCES OF FINANCING ECONOMIC DEVELOPMENT IN THE REPUBLIC OF SERBIA}

Domestic accumulation is a key factor in economic development. In the history of national economies development, there is almost no case of development without relying on own accumulation. The Republic of Serbia is among the countries with very low domestic accumulation. Nevertheless, household savings, as well as public and private sector savings, significantly affect its economic development.

\subsection{Household Savings as a Source of Financing the Economic Development of the Republic of Serbia}

Domestic savings are the most important source of investment financing in almost all countries. The level of domestic savings differs in developed countries, developing countries and countries in transition. In developed countries, domestic savings are covered by real accumulation (production of commodities), whose structure is most often dominated by products of high technological performances. These countries have a network of developed financial institutions and currencies that are mostly convertible. Developing countries and countries in transition are characterized by extremely low domestic savings, which is not covered by real accumulation, due to the inflation effect. Domestic currencies are generally not convertible, while the financial market is underdeveloped. This is also the situation in the Republic of Serbia. This is indicated by the changes in the structure and dynamics of the savings of its population in the period from 2006 to 2016 presented in Table 1. Household savings were steadily increasing in the observed period, both in dinar and foreign currency deposits. Unfortunately, high savings were not used adequately for investments, but for cash loans.

Table 1 Savings of the Republic of Serbia population (in RSD 000 000) in the period 2006 to 2016

\begin{tabular}{|c|c|c|c|c|c|c|c|}
\hline \multirow{2}{*}{ Year } & \multicolumn{3}{|c|}{ Dinar savings } & \multicolumn{3}{|c|}{ Foreign currency savings } & \multirow{2}{*}{$\begin{array}{c}\text { Total } \\
\text { savings }\end{array}$} \\
\hline & Short-term & Long-term & Total & Short-term & Long-term & Total & \\
\hline 2006 & 6,909 & 642 & 7,551 & 241,207 & 46,454 & 260,661 & 268,212 \\
\hline 2007 & 9,688 & 1,078 & 10,766 & 326,557 & 55,044 & 381,601 & 392,367 \\
\hline 2008 & 9,729 & 846 & 10,575 & 363,529 & 51,041 & 414,570 & 425,145 \\
\hline 2009 & 11,612 & 787 & 12,400 & 500,586 & 65,591 & 566,177 & 578,577 \\
\hline 2010 & 9,658 & 3,702 & 13,360 & 614,314 & 117,755 & 732,066 & 745,428 \\
\hline 2011 & 16,351 & 3,004 & 19,355 & 570,836 & 204,802 & 775,637 & 794,992 \\
\hline 2012 & 16,257 & 1,374 & 17,630 & 731,381 & 178,469 & 909,849 & 927,479 \\
\hline 2013 & 30,867 & 2,804 & 33,672 & 740,639 & 193,201 & 933,840 & 967,512 \\
\hline 2014 & 34,424 & 3,634 & 38,058 & 777,830 & 220,471 & 998,302 & $1,036,359$ \\
\hline 2015 & 34,521 & 10,843 & 45,364 & 700,668 & 313,603 & $1,014,271$ & $1,059,635$ \\
\hline 2016 & 143,115 & 7,251 & 50,366 & 861,426 & 209,529 & $1,070,955$ & $1,121,321$ \\
\hline
\end{tabular}

Source: NBS (april 2017). Statistički bilten, Beograd: NBS, p. 59.

The data given in Table 2 show that in the period from 2012 to 2016, the Republic of Serbia achieved the average GDP growth of 0.7 percent, which is close to the average level of the eurozone countries (Table 2), and out of all the bordering countries, it topped 
only Croatia. The economic growth of the Republic of Serbia amounted to 2.8 percent in 2016 and was lower than the economic growth of Albania, Bulgaria, Croatia, and Romania. Also, the economic activity in the countries of the region accelerated in the period from 2015 to 2016 compared to the period from 2012 to 2014.

Table 2 GDP growth in the Republic of Serbia, the countries of the region, the EU and the eurozone in the period 2012 to 2016

\begin{tabular}{lrrrrrr}
\hline Country & 2012 & 2013 & 2014 & 2015 & 2016 & $\begin{array}{c}\text { Average growth in the } \\
\text { period from 2012 to 2016 }\end{array}$ \\
\hline Republic of Serbia & $-\mathbf{1 . 0}$ & 2.6 & $-\mathbf{1 . 8}$ & 0.8 & $\mathbf{2 . 8}$ & $\mathbf{0 . 7}$ \\
Albania & 1.4 & 1.1 & 1.8 & 2.6 & 3.5 & 2.1 \\
B\&H & -0.9 & 2.4 & 1.1 & 3.0 & 2.0 & 1.5 \\
Bulgaria & 0.0 & 0.9 & 1.3 & 3.6 & 3.4 & 1.8 \\
Croatia & -2.2 & -1.1 & -0.5 & 1.6 & 2.9 & 0.1 \\
Hungary & -1.6 & 2.1 & 4.0 & 3.1 & 2.0 & 1.9 \\
FYR Macedonia & -0.5 & 2.9 & 3.6 & 3.8 & 2.4 & 2.4 \\
Montenegro & -2.7 & 2.9 & 1.8 & 3.4 & 2.5 & 1.6 \\
Romania & 0.6 & 3.5 & 3.1 & 3.9 & 4.8 & 3.2 \\
EU & -0.5 & 0.2 & 1.7 & 2.2 & 1.9 & 1.1 \\
Eurozone & -0.9 & -0.3 & 1.2 & 2.0 & 1.8 & $\mathbf{0 . 8}$ \\
\hline Source: worldbank.org/indicator/NY.GDP.MKTP.KD.ZG?locations=BA-BG-HR-HU-MK-ME- & RO-EU\&view=chart
\end{tabular}

In order to make up for historical lagging behind the European countries, the Republic of Serbia needs to achieve an average annual GDP growth of 4 to 5 percent over the longer term. One of the key conditions for such growth is to increase the share of investments in GDP from the current level of 18 to 19 percent to around 25 percent. Another important condition is to increase domestic savings, which would generate sufficient funds to finance investments. During the 1990s, when savings in the Republic of Serbia were particularly low due to the sanctions, there was a decrease in production. The problem of disinvestment and capital reduction from 40 to 45 percent was also reported. The lack of savings and investments particularly hit the industry, the activity in which there should be strong technical progress and where, without new investments, technology quickly becomes obsolete.

The experience of a large number of countries shows that it is necessary to allocate from 15 to 17 percent of the GDP value each year to compensate for the capital consumption (as a result of its use or flow of time) and maintain production and consumption at the same level in the future. When during the 1950s and 1960s Yugoslavia achieved high economic growth rates, savings and investments accounted for over 30 percent of GDP. In some Asian countries with high economic growth rates, savings account for between 30 and 40 percent of their GDP. In terms of the amount of savings, China particularly stands out with nearly $50 \%$ of GDP saved or invested in the domestic economy but also in the economies of many countries around the world, (Arsić, et al., 2017, p. 5).

Gross domestic savings in the Republic of Serbia amounted to 10.7 percent of GDP in 2016, which is significantly higher than in the previous years of the observed period (Table 3). Unfortunately, this amount of gross domestic saving was not enough to finance the investments necessary for maintaining a constant level of production. 
Table 3 Selected economic indicators of the Republic of Serbia in the period 2006 to 2016

\begin{tabular}{cccccccc}
\hline Year & $\begin{array}{c}\text { GDP } \\
\text { in } \\
\text { bln. \$ }\end{array}$ & $\begin{array}{c}\text { Growth } \\
\text { of GDP } \\
\text { in \% }\end{array}$ & $\begin{array}{c}\text { Gross } \\
\text { investments } \\
\text { in bln. \$, } \\
\text { current prices }\end{array}$ & $\begin{array}{c}\text { Gross } \\
\text { investme } \\
\text { nt, \% of } \\
\text { GDP }\end{array}$ & $\begin{array}{c}\text { FDI share } \\
\text { in gross } \\
\text { investments } \\
\text { in \% }\end{array}$ & $\begin{array}{c}\text { Gross } \\
\text { domestic } \\
\text { saving in bln. } \\
\text { \$, current } \\
\text { prices }\end{array}$ & $\begin{array}{c}\text { Gross } \\
\text { domestic } \\
\text { saving, \% } \\
\text { of GDP }\end{array}$ \\
\hline 2006 & 30.6 & 4.9 & 7.7 & 25.0 & 55.6 & 1.4 & 4.7 \\
2007 & 40.3 & 5.9 & 11.7 & 29.1 & 37.7 & 1.9 & 4.8 \\
\hline 2008 & 49.3 & 5.4 & 14.9 & 30.3 & 27.1 & 2.6 & 5.3 \\
2009 & 42.6 & -3.1 & 8.3 & 19.4 & 35.4 & 1.5 & 3.5 \\
2010 & 39.5 & 0.6 & 7.3 & 18.5 & 23.2 & 1.4 & 3.5 \\
2011 & 46.5 & 1.4 & 9.3 & 20.1 & 52.8 & 2.2 & 4.7 \\
2012 & 40.7 & -1.0 & 8.6 & 21.0 & 14.9 & 1.8 & 4.3 \\
\hline 2013 & 45.5 & 2.6 & 8.0 & 17.6 & 25.6 & 3.2 & 6.9 \\
2014 & 44.2 & -1.8 & 7.7 & 17.5 & 25.9 & 2.9 & 6.6 \\
\hline 2015 & 37.2 & 0.8 & 7.0 & 18.8 & 36.2 & 3.4 & 9.1 \\
2016 & 37.7 & 2.8 & 6.8 & 18.1 & 30.4 & 4.0 & 10.7 \\
\hline \multicolumn{5}{c}{ Source: worldbank.org/indicator/NE.GDI.TOTL.ZS?locations=RS } &
\end{tabular}

In the same year, the share of gross domestic saving in the countries of the region ranged from $1.5 \%$ to $29.4 \%$ of GDP (Chart 1). The Republic of Serbia surpassed only Albania and Montenegro.

Numerous theoretical and empirical studies show that in the long run, it is necessary to dominantly finance a country's investments from own funds. This means that the Republic of Serbia needs to increase domestic investment funds from about 10 percent (current level) to around 25 percent of GDP. The experience of Bulgaria, Romania, and Macedonia shows that this is possible. These countries are at a similar level of development and invest almost a quarter of GDP in investments.

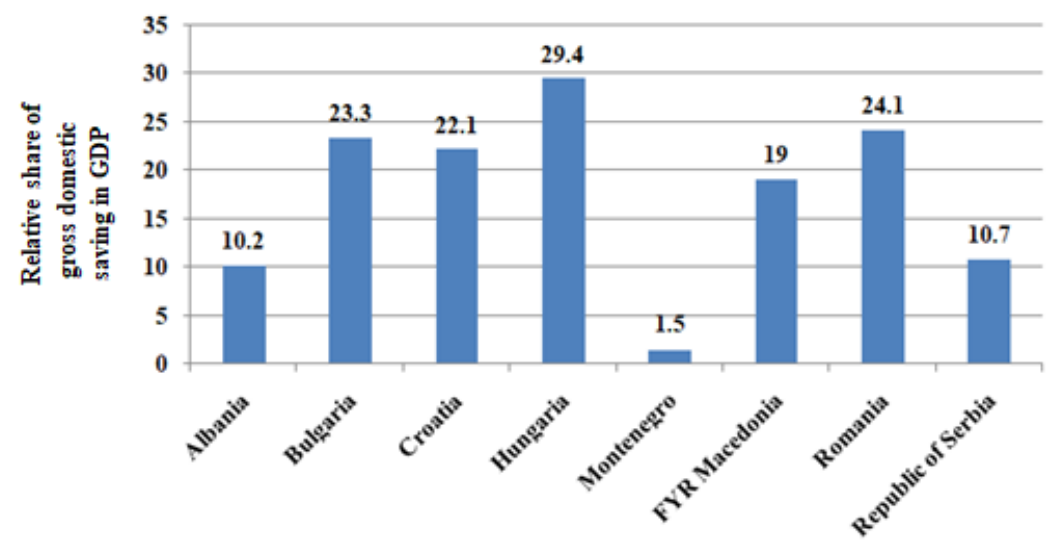

Chart 1 The share of gross domestic saving in GDP (in percent) in the Republic of Serbia and the countries of the region in 2016 Source: worldbank.org/indicator/NY.GDS.TOTL.ZS 
Total investments in fixed funds, which are the direct determinant of the economic growth in the Republic of Serbia, are relatively low. Their share in the Republic of Serbia GDP in the period from 2006 to 2016 was, on average, less than 20\% (Table 4).

Table 4 Investments of the Republic of Serbia in fixed funds in the period 2006 to 2016

\begin{tabular}{|c|c|c|c|c|c|c|c|c|c|c|c|}
\hline & 2006 & 2007 & 2008 & 2009 & 2010 & 2011 & 2012 & 2013 & 2014 & 2015 & 2016 \\
\hline $\begin{array}{l}\text { Total } \\
\text { investments in } \\
\text { fixed funds } \\
\text { (in mill. euros) } \\
\end{array}$ & 457.4 & 594.7 & 684.2 & 566.2 & 570.1 & 626.7 & 758.7 & 668.4 & 652.0 & 715.5 & 748.5 \\
\hline $\begin{array}{l}\text { Share of total } \\
\text { investments in } \\
\text { fixed funds } \\
\text { (as \% of GDP) }\end{array}$ & 22.3 & 25.3 & 24.9 & 19.7 & 18.6 & 18.4 & 21.2 & 17.2 & 16.7 & 17.7 & 17.8 \\
\hline
\end{tabular}

\subsection{Public Sector as a Source of Financing the Economic Development of the Republic of Serbia}

One of the important sources of financing economic development is public savings. There are two main sources of public savings: 1) budget surplus and 2) savings of public enterprises. A state can invest the surplus in the so-called "state cash register" (budget surplus) on the capital market annually thus improving the efficiency of the allocation of investment funds, but also the dynamics of economic growth and development. Neither high deficit nor high surplus is good, especially in less developed countries. A surplus in the budget means that the state has taken more money from the citizens and the economy through taxes than it had to. The state can increase the surplus by increasing public revenues. The growth of public revenues can be achieved by raising the existing tax rates or expanding the tax base. Additional taxes can increase public savings, but their effect may be far more pronounced on reducing private savings. It all depends on whether the marginal propensity to save is higher in the state or in the private sector. If the marginal propensity to save is higher in the private sector, it follows that the increase in taxes leading to the growth in public savings would lead to a more pronounced decrease in private and total national savings. Public enterprises generally operate less successfully than private enterprises, so their savings are very modest (Cvetanović, Mladenović, 2015, pp. 241-242).

Public sector investments in the Republic of Serbia can be divided into 1) public investments and 2) investments of public and state enterprises. Public investments positively affect GDP and represent the highest quality form of public spending (most stimulating to GDP growth). They stimulate economic growth not only in the short term, but also in the medium term, as they improve the quality of the country's infrastructure (Petrović, Brčerević, \& Minić, 2017, p. 13).

The data in the following table indicate the continued growth of the Republic of Serbia budget deficit in the period from 2006 to 2014, except in 2007, when the budget was in surplus. In 2015 and 2016, there was a sharp decrease in the budget deficit resulting from the implementation of fiscal consolidation measures. 
Table 5 Public finances of the Republic of Serbia

\begin{tabular}{cccc}
\hline Year & Budget revenues & Budget expenses & Budget surplus-deficit \\
\hline 2006 & $494,139.2$ & $522,861.3$ & $-28,722.1$ \\
2007 & $579,454.2$ & $578,818.6$ & $\mathbf{6 3 5 . 6}$ \\
2008 & $651,272.8$ & $698,771.1$ & $-47,498.3$ \\
2009 & $655,995.0$ & $748,640.0$ & $-92,645.0$ \\
2010 & $712,225.1$ & $815,148.5$ & $-102,923.4$ \\
2011 & $744,761.2$ & $880,567.2$ & $-135,806.0$ \\
2012 & $788,505.0$ & $1,001,630.5$ & $-213,125.5$ \\
2013 & $812,080.7$ & $1,012,997.9$ & $-200,917.2$ \\
2014 & $881,083.3$ & $1,127,944.7$ & $-246,861.4$ \\
2015 & $947,837.8$ & $1,062,758.7$ & $-114,920.9$ \\
2016 & $1,041,920.5$ & $1,049,867.6$ & $-7,947.1$ \\
\hline
\end{tabular}

Source: Ministarstvo finansija Republike Srbije (februar 2017). Bilten javnih finansija, 150. pp. 55-56.

Despite the fact that the increase in public investments is a country's best anti-recession policy, in the period from 2013 to 2015 their share in the Republic of Serbia GDP averaged about 2.5 percent, which is about 44 percent less than the average of the countries of Central and Eastern Europe. In 2016, public investments in the Republic of Serbia increased to 3.3 percent of GDP, but they are still below the average of the Central and Eastern European countries and countries of the region. In the coming years, the Republic of Serbia should increase the share of public investments from 2016 (3.3 percent of GDP) by about 1-1.5 percent of GDP to approach the average of the countries of Central and Eastern Europe and the countries of the region. If public investments reached the level of 5 percent of GDP and were maintained at that level in the period from 5 to 10 years, the state of public infrastructure in the Republic of Serbia would be improved appreciably.

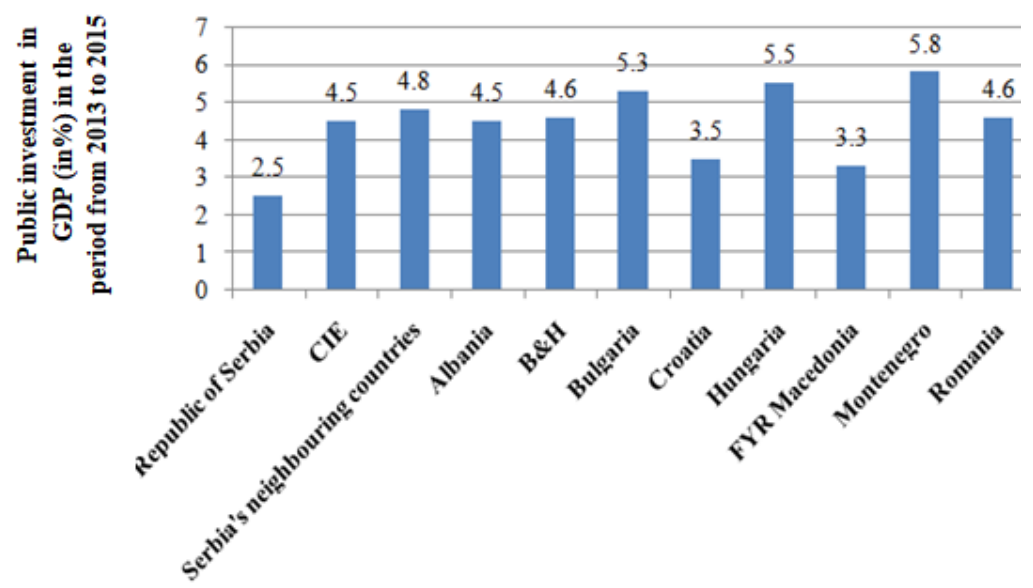

Chart 2 Relative share of public investments in GDP in the period 2013-2015 in the Republic of Serbia, countries of Central and Eastern Europe and countries of the region Source: Petrović, P., Brčerević, D., Minić, S. (2017). Fiskalna konsolidacija i prilivni rast u Srbiji 2015-2017 - plan, održavanje i pokretači. Beograd: Fiskalni savet Republike Srbije, p. 14. 
Long-term mismanagement of public and state-owned enterprises led to them creating large losses and debts, instead of stimulating economic growth and accelerating economic development through their profit-making investments. A bad example in terms of investment is EPS - the largest public enterprise in the Republic of Serbia. By 2015, this enterprise invested significantly less than the amount of depreciation, which was insufficient for it to maintain its business. Such a practice has also led to a slowdown in economic growth in the coming years.

Table 6 Investments and depreciation of EPS in the period 2013-2016 (in 000,000 RSD)

\begin{tabular}{lcccc}
\hline & 2013 & 2014 & 2015 & 2016 \\
\hline Investments & 17,556 & 24,210 & 25,184 & 49,901 \\
Depreciation & 37,354 & 38,775 & 39,592 & 44,390 \\
Investment gap & $\mathbf{- 1 9 , 7 9 8}$ & $\mathbf{- 1 4 , 5 6 4}$ & $\mathbf{- 1 4 , 4 0 8}$ & $\mathbf{5 , 5 1 1}$ \\
(Investments - Depreciation) & & & \\
\hline
\end{tabular}

Source: The table was created by the authors based on: EPS (2016).

Finansijski izveštaj od 2013 do 2016. Beograd: EPS

The results of the 2016 financial statement show that EPS' investments were greater than depreciation by about 11 percent, while in 2015 they were by about 36 percent lower than depreciation. In 2016, investments were about 50\% higher than in 2015, indicating that production capacity could increase, which would lead to a reduction in imports of electricity and therefore in foreign trade deficit. The estimates of experts in this field indicate that at least $1 \%$ of GDP is a lack of investment in the Republic of Serbia due to unsuccessful operations and insufficient investment of public and state enterprises (Petrović, Brčerević, \& Minić, 2017).

Because of this, very important levers for increasing investments and accelerating economic growth and development in the Republic of Serbia include: 1) urgent public enterprise reform, and 2) resolving the fate of failed public enterprises through privatization or bankruptcy. By increasing public investments, reforming public enterprises and privatizing state-owned enterprises could increase the share of total investments in the Republic of Serbia from current 18 percent to 20-21 percent of GDP. This would be a significant step towards bringing the share of total investments in the Republic of Serbia closer to the desired level of 25 percent of GDP (Petrović, Brčerević, \& Minić, 2017, p. 15).

However, it is desirable for most investments to be generated by the private sector. Domestic and foreign private entrepreneurs on one part and the state on the other should invest over 20 percent and 4 to 5 percent of GDP, respectively. "Government investment is now about $3 \%$ of GDP, while domestic investment is $10 \%$ of GDP and, together with foreign investment, accounts for around 15\% of GDP" (Milovanović, Radisavljević, Đukić, 2018, p. 37-38). It is evident that government and private investments in the Republic of Serbia are now insufficient to achieve a high rate of economic growth. Increasing private investments to around 15 percent of GDP, as well as increasing investments in infrastructure, are key to accelerating the economic growth of the Republic of Serbia. 


\subsection{The Role of Private Sector in Financing the Economic Development of the Republic of Serbia}

The main source for long-term financing of investments in the world, and so in the Republic of Serbia, is domestic private savings. The role of the state is very important for encouraging private investments and it is reduced primarily to the improvement of the investment environment, which in the Republic of Serbia, despite significant improvements, has been assessed by the relevant international institutions as insufficiently competitive. Thus, on the Doing Business list of the World Bank for 2017 including 190 economies, the Republic of Serbia economy was ranked $47^{\text {th }}$, which is quite an improvement compared to the previous few years (http://www.doingbusiness.org/ /media/WBG/DoingBusiness/ Documents/Annual-Reports/English/DB17-Report.pdf).

The list of the World Economic Forum, which is more comprehensive than the World Bank's list, shows that the Republic of Serbia was ranked 78th out of 137 countries for the $2017 / 2018$ period and improved its position by 12 places compared to the $2016 / 2017$ report, when it was ranked $90^{\text {th }}$ out of 138 ranked countries (http://www3.weforum.org/docs/ GCR2017-2018/05FullReport/TheGlobalCompetitivenessReport2017\%E2\%80\%932018.pdf).

By the corruption perceptions index of Transparency International, the Republic of Serbia was found in the $72^{\text {nd }}$ position in 2016 (https://www.transparency.org/news/feature/ corruption_perceptions_index_2016). It follows that in all observed lists, the Republic of Serbia is poorly ranked in terms of the efficiency of institutions and the commodity market, financial market development, business sophistication, legal protection of proprietary rights, the fulfillment of contracts, the efficiency of issuing court rulings and the perception of corruption.

Poor economic environment affects the low investment of domestic, small and mediumsized enterprises and entrepreneurs to the greatest extent, while foreign and large domestic enterprises find it easier to invest in the Republic of Serbia. Favoring foreign investment capital and marginalizing potential domestic sources of financing have influenced the level of their investments. In the myriad of approved subsidies, $75 \%$ of the value is assigned to foreign investors, although domestic ones are more numerous individually, but with far smaller amounts. Due to this type of ignoring, some of the biggest Serbian entrepreneurs are investing excess capital in neighboring countries. For example, Delta Holding, which generated around 10 percent of GDP from 2009 to 2010, is now investing actively in Slovenia, the Republic of Srpska, Bulgaria, and Albania. MK Group is investing its capital in Slovenia and Montenegro and announcing withdrawal from the Republic of Serbia. Vuk Hamović, the coowner of the EFT Group, which generates almost 98 percent of its revenues in the EU and the region, has invested a large sum of money in the Stanari Thermal Power Plant in the Republic of Srpska. Branislav Grujić, the co-owner of PSP Farman, has moved almost all of his business from the Republic of Serbia to places around the world (Brkić, 2017, p. 30). In order for entrepreneurs to be stimulated and have more benefits from investments, the Republic of Serbia must adopt an entrepreneurship development strategy that will direct and accelerate the development of entrepreneurship through legislation. 


\section{FOREIGN SECTOR AS A SOURCE OF FINANCING THE ECONOMIC DEVELOPMENT OF THE REPUBLIC OF SERBIA}

Foreign sector (all entities from economic or social life coming from other countries) generates two types of sources of financing for the economic development of the Republic of Serbia: 1) private and 2) public.

Due to the low level of per capita income and low savings rates, developing countries are unable to provide the necessary funds to finance domestic savings investments. Therefore, they are forced to obtain part of the funds necessary for financing economic development from foreign sources. Funds engaged from abroad can be an adequate supplement to domestic savings and a driving force for exiting the so-called vicious circle of underdevelopment.

The key issue in analyzing the purposefulness of engaging foreign savings to finance economic development is the efficiency of using someone else's resources. In case of failed investments, not only will the income to repay foreign savings not be generated, but a loss will be created that absorbs part of the domestic savings for its coverage. Therefore, financing failed investments by engaging foreign savings leads to problems in repayment of debts and to a reduction in the rate of economic growth (Cvetanović, Mladenović, 2015, p. 268).

Even when domestic savings are sufficient to finance economic development, foreign savings are not absolutely unnecessary. In the event that the observed country does not dispose of enough foreign funds, this deficit will condition the slowdown in economic growth, so that part of the domestic savings will be unused as well. Therefore, foreign capital not only stimulates domestic savings if insufficient, but also allows the import of goods necessary for economic growth and development (Cvetanović \& Mladenović, 2015, p. 268).

The following table gives an overview of foreign sources of financing of the Republic of Serbia in the period from 2007 to 2016. It is evident that the FDIs in 2011 reached a record of 3.3 billion euros. They represent a significant contribution to the expansion of investment activities in the Republic of Serbia. The inflow of portfolio investments in 2013 amounted to 1.9 billion euros. In the period from 2014 to 2016, there was a significant decrease in portfolio investments, and in 2015 and 2016 their inflow even had a negative balance.

Table 6 Overview of foreign sources of financing in the Republic of Serbia in the period from 2007 to 2016 (in EUR 000,000)

\begin{tabular}{lrrrrrrrrrrr}
\hline $\begin{array}{l}\text { Type of foreign } \\
\text { sources }\end{array}$ & 2007 & 2008 & 2009 & 2010 & 2011 & 2012 & 2013 & 2014 & 2015 & 2016 \\
\hline Net FDI & 2,528 & 2,486 & 2,068 & 1,133 & 3,320 & 753 & 1,298 & 1,236 & 1,804 & 1,861 \\
$\begin{array}{l}\text { Net portfolio } \\
\text { investments }\end{array}$ & 678 & -91 & -49 & 67 & 1,600 & 1,676 & 1,883 & 369 & $\mathbf{- 2 8 9}$ & $\mathbf{- 9 1 6}$ \\
Other investments & 2,884 & 2,516 & 2,626 & -549 & 197 & -214 & -855 & $-1,703$ & -141 & -448 \\
\hline In total: & 6,090 & 4,911 & 4,645 & 651 & 5,117 & 2,215 & 2,326 & -98 & 1,374 & 497 \\
\hline
\end{tabular}

Note: Net outflow (-), net inflow (+)

Source: Ministarstvo finansija Republike Srbije (april 2017). Bilten javnih finansija, 152.

Beograd: Ministarstvo finansija, p. 28; Statistika platnog bilansa Republike Srbije 2007-2016. Available at: www.nbs.rs/internet/cirilica/80/platni_bilans.html

Based on the analysis of the total volume of FDIs in the five largest sectors/industries in the period from 2010 to 2016 , it can be concluded that on average $52.4 \%$ of FDIs were 
realized in the service sector/industry. Most of the FDIs were used for the purchase of assets of private, state-owned and social enterprises and banks in the process of tender and auction privatization. In 2007 and 2008, the greatest investments were recorded in the Financial intermediation (about 40 percent of investments), and in the first half of 2009 in industries such as ore exploitation and stone exploitation. Analyzing the FDI inflows into the service sector/industry, we may observe a trend of significant reduction from 2010 to 2016 - from 61.4 percent in 2010 to 41.3 percent in 2016 . There is also a noticeable increase in FDI in the processing industry and construction, from 38.6 percent in 2010 to 58.7 percent in 2016 (Table 7).

Table 7 Structure of FDI inflows to the Republic of Serbia by sectors/industries in the period from 2010 to 2016 (in 000.000 euros and percent)

\begin{tabular}{|c|c|c|c|c|c|c|c|c|}
\hline Sector/industry & 2010. & 2011. & 2012. & 2013. & 2014. & 2015. & 2016. & Average \\
\hline Processing industry & 329,0 & 631,0 & 521,0 & 679,0 & 535,0 & 721,0 & 712,0 & 590,0 \\
\hline Financial intermediation $^{2}$ & 424,0 & 840,0 & 291,0 & 141,0 & 358,0 & 484,0 & 423,0 & 423,0 \\
\hline Wholesale and retail & 133,0 & $1.019,0$ & 194,0 & 300,0 & 225,0 & 208,0 & 188,0 & 324,0 \\
\hline Construction & 35,0 & 92,0 & 19,0 & 67,0 & 163,0 & 264,0 & 259,0 & 129,0 \\
\hline $\begin{array}{l}\text { Traffic, storage and } \\
\text { communications }\end{array}$ & 21,0 & 66,0 & 17,0 & 71,0 & $-9,0$ & 68,0 & 73,0 & 44,0 \\
\hline $\begin{array}{l}\text { Total five largest sectors / } \\
\text { industries }\end{array}$ & 942,0 & $2.648,0$ & $.042,0$ & 258,0 & $.272,0$ & $.745,0$ & $1.655,0$ & $1.510,0$ \\
\hline Total FDI inflow & $1.278,0$ & $3.544,0$ & $1.009,0$ & $1.548,0$ & $1.500,0$ & $2.114,0$ & $2.080,0$ & $1.868,0$ \\
\hline $\begin{array}{l}\text { Share in total net inflow } \\
\text { of FDI }\end{array}$ & 73,7 & 74,7 & 103,0 & 81,3 & 84,8 & 82,5 & 79,6 & 80,8 \\
\hline
\end{tabular}

Source: Statistika platnog bilansa, strana direktna ulaganja, neto obaveze, po delatnostima, 2010-2016. Available at: www.nbs.rs/internet/cirilica/80/platni_bilans.html

By observing the average share of the service sector and the average share of the manufacturing sector in the cumulative average of the five largest sectors, we may note that service sectors account for 52.4 percent while manufacturing sectors account for 47.6 percent. The data in Table 7 show that service sectors/industries (Financial intermediation, Wholesale and retail, Transport, storage and communications) have the largest share in GDP creation while manufacturing sectors (Processing industry and Construction) show significant progress in the creation of GDP.

The Republic of Serbia has not built the systemic capacity for economic growth yet, as the reforms were implemented in one step forward, two steps back. In the political, social and especially economic systems, there are serious built-in inhibitors of economic growth. The estimates by the World Bank, the IMF, the European Commission, and rating companies indicate which reforms the Republic of Serbia has to implement to create key preconditions for further growth of its economy.

Table 8 shows the percentage share of net FDI in GDP in the ten selected countries. "In the period from 2013 to 2015, the relative share of net FDI in GDP in the Republic of Serbia was low, compared to most of the countries observed. The reasons are the

\footnotetext{
${ }^{2}$ The Industry which by the Classification of Activities belongs to the sector "Financial and insurance activities" and "Financial services, except insurance and pension funds".
} 
following: unstable political situation, frequent elections, government reconstruction, and high budget deficit and public debt. All this gave investors an indication of an unstable environment. During 2015 and 2016, there was a slight increase in the relative share of net FDI in GDP" (Milovanović, Radisavljević, Đukić, 2018, p. 39), which points to a positive prospect for future GDP growth and increase in the export potential of the Republic of Serbia.

Table 8 Relative share of net FDI in GDP in selected countries

\begin{tabular}{lrrrrrc}
\hline & 2012 & 2013 & 2014 & 2015 & 2016 & $\begin{array}{c}\text { Average in the } \\
\text { period from } \\
\text { 2012 to 2016 }\end{array}$ \\
\hline Albania & 7.5 & 9.8 & 8.7 & 8.7 & 9.2 & $\mathbf{8 . 8}$ \\
B\&H & 2.3 & 1.7 & 2.8 & 1.8 & 1.6 & $\mathbf{2 . 0}$ \\
Bulgaria & 3.3 & 3.6 & 3.6 & 5.5 & 2.4 & $\mathbf{3 . 7}$ \\
Montenegro & 15.2 & 10.0 & 10.8 & 17.4 & 5.4 & $\mathbf{1 1 . 8}$ \\
Czech Republic & 4.5 & 3.5 & 3.9 & 0.9 & 3.4 & $\mathbf{3 . 2}$ \\
Croatia & 2.6 & 1.6 & 6.9 & 0.3 & 1.9 & $\mathbf{2 . 7}$ \\
Macedonia & 3.5 & 3.7 & 0.5 & 3.0 & 5.3 & $\mathbf{3 . 2}$ \\
Hungary & 8.3 & -2.8 & 9.3 & -4.4 & -7.3 & $\mathbf{0 . 6}$ \\
Republic of Slovakia & 1.9 & 1.0 & -0.4 & 1.3 & 4.0 & $\mathbf{1 . 6}$ \\
Republic of Serbia & $\mathbf{2 . 4}$ & $\mathbf{3 . 8}$ & $\mathbf{3 . 7}$ & $\mathbf{5 . 4}$ & $\mathbf{5 . 5}$ & $\mathbf{4 . 2}$ \\
Average & $\mathbf{5 . 2}$ & $\mathbf{3 . 6}$ & $\mathbf{5 . 0}$ & $\mathbf{3 . 1}$ & $\mathbf{3 . 1}$ & $\mathbf{4 . 2}$ \\
\hline
\end{tabular}

Source: Milovanović, Radisavljević, Đukić, 2018, p. 40.

If we look at the average share of net FDI in GDP for selected countries by years, we will see that it peaked in 2012 (5.2 percent). In 2013, this share dropped to 3.6 percent to grow again in 2014 to 5 percent. In 2015 and 2016, the share of net FDI in GDP again dropped to 3.1 percent, while the aggregate average for the share of net FDI in GDP for selected countries was 4.2 percent (Table 8).

Although the Republic of Serbia has accomplished a solid result in the FDIs inflow so far, the fact is that they have not significantly contributed to stopping the deindustrialization process. It turned out that FDIs were crucial for the transfer of new technologies and productivity growth, which resulted in higher quality and higher export volumes. The export of the Republic of Serbia, primarily the export of products from newly established companies, "has increased significantly to countries from which large FDI inflows came, such as Italy and Germany" (Milovanović, Radisavljević, Đukić, 2018, p. 38).

FDIs had a significant impact on the exports of the countries of Central and Eastern Europe as well as their integration into the world economy and the transfer of modern technology. During the initial transition phase, the largest cumulative inflow of FDI was recorded in countries such as the Czech Republic, Hungary, Slovakia, and Poland. It is the FDI that came to these countries that affected the restructuring, i.e. the reorientation of production from low-level finished products such as clothing and furniture to automotive and IT components for further production (Nikolić, 2017, p. 134).

In the Republic of Serbia, since the global economic crisis, the focus has shifted to implementing FDIs in the processing industry. Tax incentives for the employment of new workers and the free infrastructure necessary for the operation of companies in the form 
of technological parks have been granted. "It is encouraging that the share of FDI in industry in recent years was almost two fifths on average, which is twice the average for the first decade of the 21st century" (Milovanović, Radisavljević, Đukić, 2018, p. 39).

It is encouraging that the share of FDIs in the industry in recent years has on average been almost two fifths, which is twice the average for the first decade of the $21^{\text {st }}$ century.

The practice so far has shown that FDIs positively affect economic development only if the recipient country has a complementary industry, as the impact of multinational companies, as the largest FDI generators, on economic development is mainly made through cooperation with local producers. If a foreign company comes, with another foreign company as the supplier, and a third foreign company as the distributor, then there is no real effect on the economic development of the host country. The development effects of FDIs are only possible when there is a connection with local businesses and when there is a "spillover effect" of technology and knowledge (Nikolić, 2017, p. 134).

Economists point out that an established annual FDI inflow of at least 1.6 billion euros is required for stable and long-term growth of the economy of the Republic of Serbia. In order to achieve this, the Republic of Serbia must create a motivating and predictable business environment entailing a normal situation where investors come from the world, motivated to work well and earn.

Over the past two decades, there have often been controversies about the impact of state subsidies on attracting FDIs to the Republic of Serbia. Previous experience has shown that most of the poor countries used state subsidies in their development. It is logical that the Republic of Serbia too must give subsidies so as not to be removed from the investment map and that these subsidies must bring foreign investors that will provide more jobs, better wages, higher exports, higher production and better filling of the state budget.

A country that relies heavily on subsidies clearly shows that it is trying to make up the weaknesses that exist in its economic environment. It is true that some investors will come for subsidies. However, more investors would come if conditions for investment were better, if the state functioned better, and if there were financial discipline and highly educated workforce. Then we could talk about attracting better quality FDIs. For if a company comes only for incentives, then it means that it is not among the best-ranked ones. Interesting are IBM data in the Global Location Trends - 2016 Annual Report, according to which the Republic of Serbia is a good place to invest in, but that assessment would be much more convincing when certain companies invest without taking state subsidies.

\section{CONCLUSION}

Developed countries have a favorable savings structure as their domestic currency is convertible and there is no difference between savings in domestic and savings in foreign currencies. In developed countries, monetary savings are covered by real accumulation. In these countries, household savings is the main source of economic development. Unlike developed countries, developing countries are characterized by extremely low savings, where cash savings are not covered by real accumulation. Household savings in these countries are insufficient to finance their economic development.

By analyzing the impact of domestic and foreign sources of financing on the economic development of the Republic of Serbia, we have come to the conclusion that domestic 
sources of financing are more desirable than foreign ones. If it wants to count on high growth rates, the Republic of Serbia has to increase domestic savings in the coming period in order to increase total investments from around 18 percent of GDP to 25 percent of GDP. In order to accelerate economic growth, it is necessary to increase domestic private investment from the current 10 percent to 15 percent of GDP; remove administrative barriers to domestic investors and treat them equally with other investors; continue to build the infrastructure. The economic development of the Republic of Serbia would be even more intense if domestic investors were given the chance to invest and get incentives just like foreign investors.

The results show that both public and private investments in the Republic of Serbia are significantly less than they should be. If it wants to achieve high economic growth rates, the Republic of Serbia needs to increase public investments from the current 3-3.5 percent to 4-5 percent of GDP.

Due to a deficiency in domestic accumulation, the Republic of Serbia needs foreign capital in the form of FDIs. FDIs now reach around 5 percent of GDP, which is a solid result. Higher FDI inflows could lead to the repatriation of profits and balance of payments issues.

The state needs to improve macroeconomic stability so that enterprises can borrow under favorable conditions and generate high profits, from which they could invest in their development. For the lasting stability of the economy, it is crucial to eliminate great fiscal and foreign trade deficits as they can lead to a debt crisis. When they feel the hint of the debt crisis, entrepreneurs usually postpone or permanently give up on investments. Under such conditions, they are aware of the fact that they cannot count on state support and that they can lose capital and go bankrupt.

\section{REFERENCES}

Arnold, J.M. \& Javorcik, B.S. (2009). Gifted kids or pushy parents? Foreign direct investment and plant productivity in Indonesia. Journal of International Economics, 79 (1), 42-53.

Arsić, M. et al. (2017). Kvartalni monitor ekonomskih trendova i politika u Srbiji [Quarterly Monitor of Economic Trends and Policies in Serbia]. Br. 47, oktobar-decembar 2016. Beograd: Fond za razvoj ekonomske nauke.

Brkić, M. (2017). Istina o Srpskoj ekonomiji [The truth about the Serbian economy]. Nedeljnik, br. 296, 30-32. Corruption Perception Index 2016. Retrieved from:

https://www.transparency.org/news/feature/corruption_perceptions_index_2016. Accessed on: 26 December 2018.

Cvetanović, S. (2005). Teorija privrednog razvoja [Theory of Economic Development]. Niš: Ekonomski fakultet.

Cvetanović, S. \& Mladenović, I. (2015). Ekonomija kapitala i finansiranje razvoja [Capital Economics and Development Financing]. Niš: Ekonomski fakultet.

Doing Business 2017 - Equal Opportunity for All. Retrieved from: http://www.doingbusiness.org/ /media/ WBG/DoingBusiness/Documents/Annual-Reports/English/DB17-Report.pdf. Accessed on: 30 November 2018.

EPS. (2016). Finansijski izveštaj od 2013 do 2016 [Financial Reports 2013-2016]. Beograd: EPS.

Hagemejer, J. \& Tyrowicz, J. (2012). Is the effect really so large? Firm-level evidence on the role of FDI in a transition economy. Economics of Transition, 20 (2), 195-233.

Lewis, A. (1966). Development Planning. London: Allen \& Unwin.

Milovanović, G., Radisavljević, G. \& Đukić, G. (2018). Dependence of Serbian Economic Development on Foreign Direct Investment Flows. Ekonomika, 64 (1), 33-42.

Ministarstvo finansija Republike Srbije (februar 2017). Bilten javnih finansija [Bulletin of Public Finance]. 150, Beograd: Ministarstvo finansija.

Ministarstvo finansija Republike Srbije (april 2017). Bilten javnih finansija [Bulletin of Public Finance]. 152. Beograd: Ministarstvo finansija. 
Moura, R. \& Forte, R. (2010). The effects of foreign direct investment on the host country economic growththeory and empirical evidence, No. 390. Porto: Universidade do Porto, Faculdade de Economia do Porto.

Nikolić, G. (2017). Razbijanje ekonomskih mitova [Breaking economic myths]. Beograd: Arhipelag i Institut za evropske studije.

Petrović, P., Brčerević, D. \& Minić, S. (2017). Fiskalna konsolidacija i privredni rast u Srbiji 2015-2017 plan, ostvarenja $i$ pokretači [Fiscal consolidation and economic growth in Serbia 2015-2017 - plan, achievements and drivers]. Beograd: Fiskalni savet Republike Srbije.

Rostow, W.W. (ed.) (1963). The Economics of Take-off into Sustained Growth. London: Palgrave Macmillan.

Samuelson, P. \& Nordhaus, W. (1992). Ekonomija. XIV ed. Zagreb: Mate.

Statistika platnog bilansa, strana direktna ulaganja, neto obaveze, po delatnostima, 2010-2016. godina [Balance of payments statistics, foreign direct investments, net liabilities, by activities, 2010-2016]. Retrieved from: www.nbs.rs/internet/cirilica/80/platni_bilans.html. Accessed on: 22 December 2018.

Statistika platnog bilansa Republike Srbije 2007-2016. godina [Balance of Payments Statistics of the Republic of Serbia from 2007 to 2016.]. Retrieved from: www.nbs.rs/internet/cirilica/80/platni_bilans.html. Accessed on: 11 November 2018.

Statistički bilten [Statistical Bulletin]. April 2017. Beograd: NBS.

The Global Competitiveness Report 2017-2018. http://www3.weforum.org/docs/GCR2017-2018/05FullReport/ TheGlobalCompetitivenessReport2017\%E2\%80\%932018.pdf. Accessed on: 14 November 2018.

Todorović, M. (1998). Uvoz kapitala i privredni razvoj [Imports of capital and economic development]. Beograd: Zadužbina Andrejević.

www.worldbank.org/indicator/NE.GDI.TOTL.ZS?locations=RS. Accessed on: 25 November 2018.

www.worldbank.org/indicator/NY.GDP.MKTP.KD.ZG?locations=BA-BG-HR-HU-MK-ME-RO-

EU\&view=chart. Accessed on: 28 December 2018.

www.worldbank.org/indicator/NY.GDS.TOTL.ZS. Accessed on: 29 December 2018.

\section{UTICAJ DOMAĆIH I STRANIH IZVORA FINANSIRANJA NA PRIVREDNI RAZVOJ REPUBLIKE SRBIJE}

Cilj rada je da se na bazi sistematizovanih statistickih podataka analiziraju uticaji odabranih izvora finansiranja na privredni razvoj Republike Srbije u periodu od 2012. do 2016. godine. Najpre se, iz ugla savremene teorije, prezentuju teorijski okviru domaćih i stranih izvora finansiranja i uticaji ovih izvora na privredni razvoj. Sledi analiza uticaja domaćih izvora finansiranja (domaća štednja, državni i privatni sektor) na privredni razvoj Republike Srbije. $\mathrm{Na}$ kraju se analizira relevantnost stranih direktnih investicija (SDI) za podsticanje restrukturiranja, konkurentnosti, rasta i razvoj privrede Republike Srbije.

Ključne reči: domaći izvori, strani izvori, SDI, BDP, privredni razvoj 